\title{
Post-Harvest Handling Holstein Friesian Milk at Susu Abadi Company in Tegal District
}

\author{
Krisjayanti Ataqwa* and Melly Fera \\ Program Studi Ilmu dan Teknologi Pangan, Fakultas Sains dan Teknologi, Universitas Muhadi Setiabudi \\ Brebes \\ e-mail: krisjayantiattaqwa9640@gmail.com,melly.fera@umus.ac.id
}

\begin{abstract}
Dairy cows are very important producers of animal protein. Milk as a source of nutrition in the form of animal protein is very beneficial. This study aims to determine the post-harvest process of Friesien Holsein's cow's milk in a susu abadi company in Tegal Regency. This research uses descriptive qualitative research. The sampling method for this research was purposive sampling method. Data collection methods used were observation, interviews, and documentation. The milking process in susu abadi companies is carried out twice a day, namely at 05.00 WIB and second at 15.00 WIB. After the milking process goes through the filtering stage, the resulting milk is filtered. a strainer made of cotton or a clean white cloth. In susu abadi company, large quantities of freshly milked fresh milk should be immediately cooled from $37^{\circ} \mathrm{C}$ to $4^{\circ} \mathrm{C}$ in order to maintain the milk temperature during $4^{\circ} \mathrm{C}$ storage. Volume of milk heated at a temperature of 62 $65^{\circ} \mathrm{C}$ for 30-60 minutes. After the pasteurization process, the milk is put into a container and the milk is packed in a plastic bag with a volume of 1 liter. There are two products produced in susu abadi companies, namely fresh milk and pasteurized milk. Laboratory tests to determine the quality of milk produced by taking milk samples to be checked for quality.
\end{abstract}

Keywords : milk, post harvest, FH, company

\section{Introduction}

Population growth in Indonesia is increasing, which is not accompanied by awareness of the importance of animal protein for body health, which has an impact on the demand for animal products such as meat and milk. Dairy cows are very important producers of animal protein. Breast milk as a source of nutrition in the form of animal protein is very beneficial for babies, for those who are in the process of growth and even for the elderly. Because milk from dairy cows has a very high protein content, it is very supportive of growth, intelligence, and endurance.

Cow's milk is a nutritious white liquid produced by the mammary glands of female mammals. Milk is the main source of nutrition for babies before they can digest solid foods. Milk is the raw material for all dairy products, which are mostly used as food products. One of the dairy cows in Indonesia is Friesien Holsein (FH), the productivity of FH cows in Indonesia is still low with an average milk production of 10 liters / head / day or approximately $3,050 \mathrm{Kg} /$ lactation [1] which is still lower if compared to FH cows if raised in America which can produce more than $7,000 \mathrm{~kg}$ of milk in 1 lactation period [2].

The market in the Indonesian industry is still quite large and very potential where the consumption of milk in Indonesia is currently still low when compared to other countries. An increase in milk production will occur if the maintenance management and processing of dairy cow's milk are carried out properly. The productivity of FH cattle, especially for milk production, is influenced by genetic, environmental and the interaction of these two factors. 70 percent of milk production is influenced by environmental factors which are divided into external and internal environment.

The low quality of milk produced by smallholder farms is a result of the management system for handling milk that is not up to standard, so that it impacts on the low price of milk for farmers, which is relatively inexpensive by the Milk Processing Industry. Milk is a material that 
is pure, hygienic, high nutritional value, contains few germs or it can be said that milk is still sterile. Likewise, smell and taste do not change and are harmless to drink, so it is necessary to have a proper way to handle milk after harvest. Especially the semi traditional method of harvesting milk.

The way to extend the shelf life of milk, namely by heating (pasteurization) is one of the methods used to prevent milk damage to minimize the growth of pathogenic bacteria that can be harmful to human health. This study aims to determine the post-harvest process of Friesien Holsein's cow's milk in a susu abadi company in Tegal Regency.

\section{Research methods}

This research was conducted at the susu abadi company in the city of Tegal for 30 days. The object of this research is the owner of the company and employees of the susu abadi company in the city of Tegal. This research uses descriptive qualitative research. The descriptive qualitative method in this study adjusts the opinion between the researcher and the informant so that the researcher can more clearly describe all the phenomena that exist in the research location.

The sampling method for this research was purposive sampling method. The sampling method in this study is using purposive sampling method, which is sampling based on certain objectives or considerations [3]. Data collection methods used were observation, interviews, and documentation [4]. The data validity checking technique used three methods, namely: triangulation, observation, and discussion with friends. The data analysis technique used the interactive model of Miles and Herberman's analysis through four stages, namely data collection, data reduction, data presentation and conclusion drawing [5].

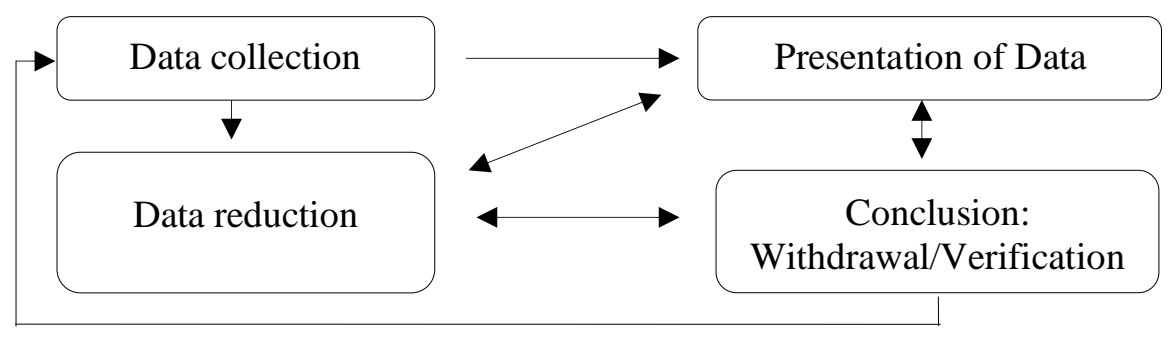

Figure 1. The Process of Qualitative Research Data Analysis

\section{Discussion}

Susu abadi company is a company that produces milk for dairy cows located in Pepedan Village, Dukuhturi District, Tegal Regency, Central Java Province. In 2019 the remaining cows are 15 female cows and 5 calves. To meet market needs, the susu abadi Company supplies milk from milk-producing small and medium enterprises (SMEs) in the Kuningan area of West Java with an amount of 2000 liters per 2 days. The number of employees in the animal husbandry sector is 15 people who are divided into three parts, namely the dairy cow production section, composting and cow feed making, and the administration section for each employee has different fields and responsibilities for parts such as cow's milk production and admin in company. Susu Abadi company can be an example for young people to develop this business because it is very profitable [6].

\subsection{Milking}

The milking process in susu abadi companies is carried out twice a day, namely at $05.00 \mathrm{WIB}$ and second at $15.00 \mathrm{WIB}$. In the milking technique, two methods are used, namely manually and using a milking machine. Because there are some cows that are sensitive to using the milking machine. 
Before milking the cow's nipples and udders must be cleaned first so that they do not become contaminated with feces that enter the milk [7].

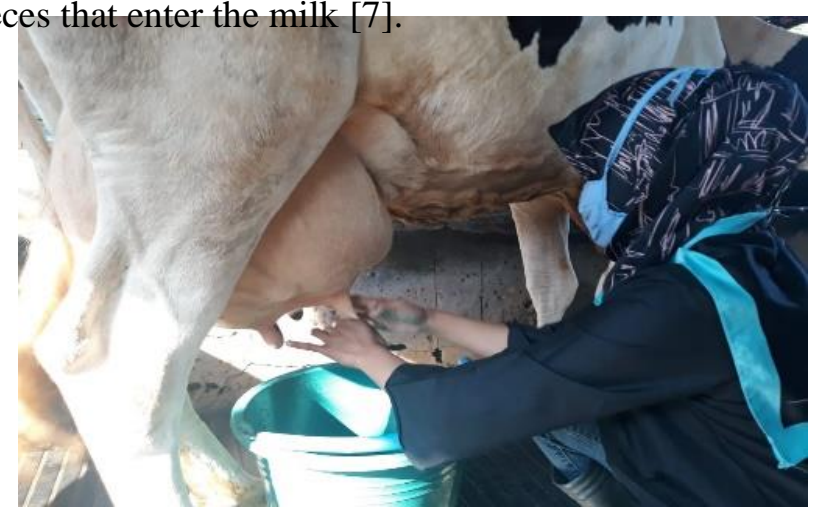

Figure 2. Cow Milking

\subsection{Milk Filtering}

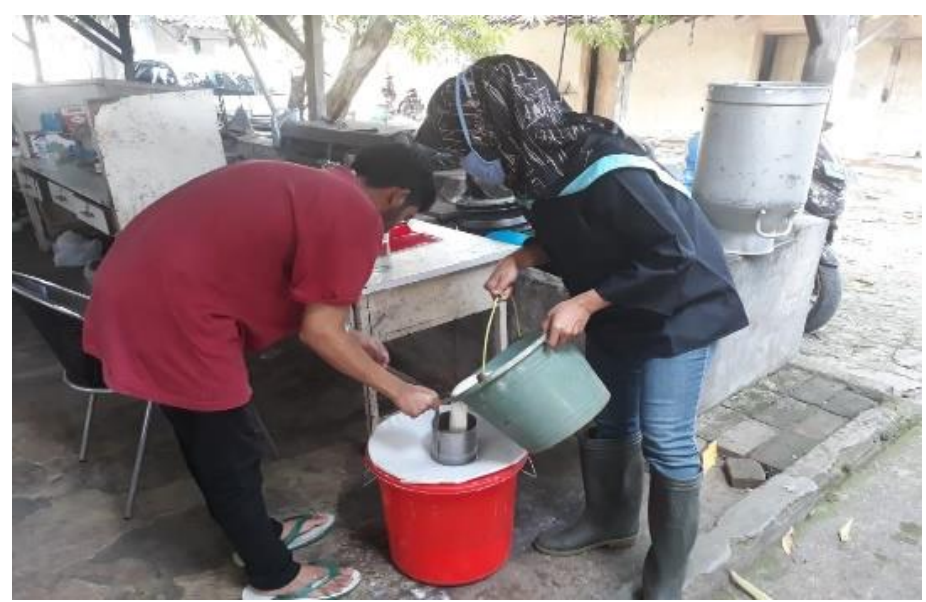

Figure 3. Cow's Milk Filtering Process

After the milking process goes through the filtering stage, the resulting milk is filtered. a strainer made of cotton or a clean white cloth. Milk is poured from one container to another and a filter cloth is placed in the mouth of the funnel which is intended for the milk container [8]. Filtering is carried out to ensure that no foreign objects enter and have the potential to damage the milk, such as hair and other impurities that enter the milk during milking [9].

\subsection{Cooling Milk}

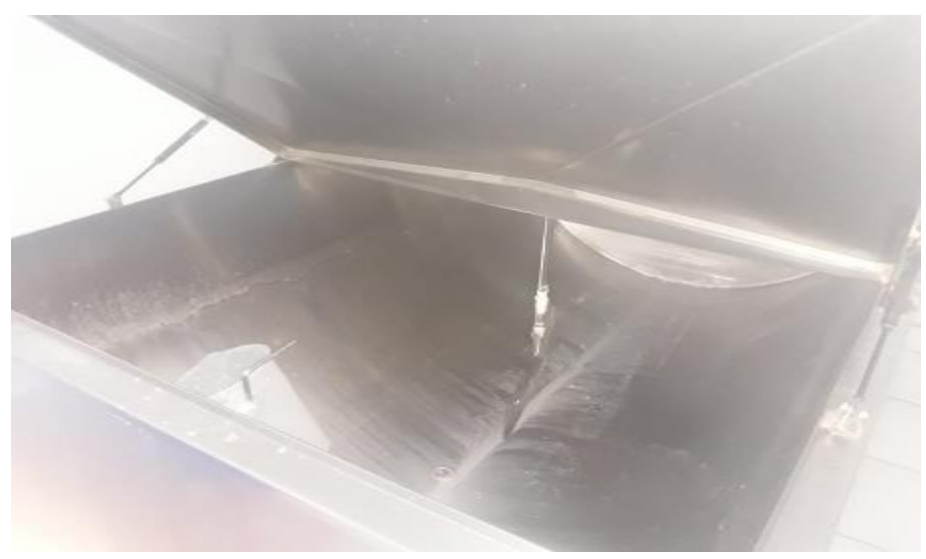

Post-Harvest Handling Holstein Friesian Milk at Susu Abadi Company in Tegal District (Krisjayanti Ataqwa and Melly Fera) 
Figure 4. Cooling equipment at the susu abadi company

After the filtering process, the milk is immediately taken to the cooling room, the milk is placed into a special cooling tank (cooling unit) in a cooling unit equipped with a stirrer or a specific system to achieve a certain hygienic standard. In susu abadi company, large quantities of freshly milked fresh milk should be immediately cooled from $37^{\circ} \mathrm{C}$ to $4^{\circ} \mathrm{C}$ in order to maintain the milk temperature during $4^{\circ} \mathrm{C}$ storage. Until the milk is ready to be processed or marketed to consumers [10].

\subsection{Heating Milk}

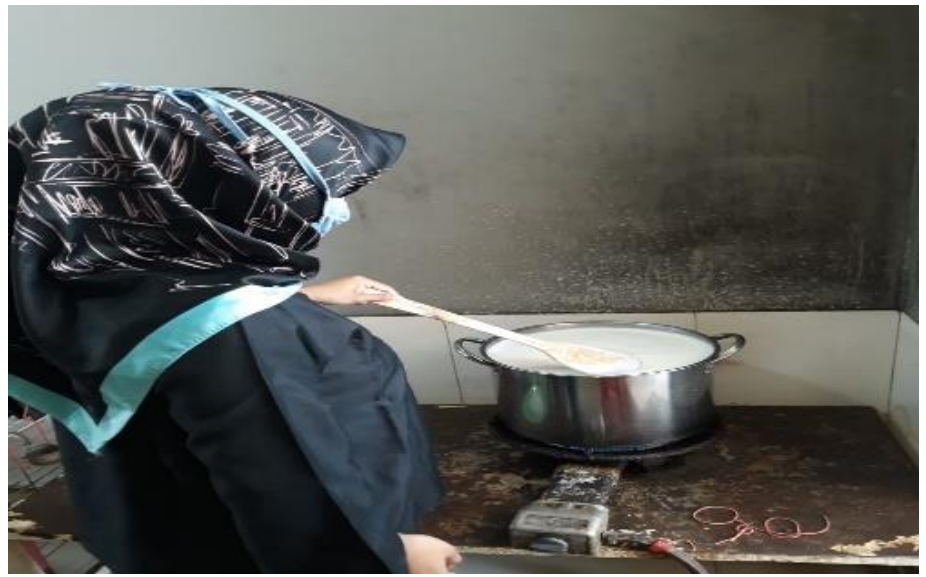

Figure 5. The Process of Heating Milk

Heating milk is done to kill microbes that destroy milk and kill germs in milk that can endanger human health. In heating milk or pasteurization in a susu abadi company, heating milk is brought to a boiling temperature to kill germs and pathogenic bacteria using a long pasteurization (law tempetarute long time) by heating milk which is carried out at a temperature that is not high for a relatively long time depending on the volume of the milk being heated at temperatures of $62-65^{\circ} \mathrm{C}$ for $1 / 2-1$ hour [11]. The milk is heated until it boils and then stored in a safe and clean place. The heating of the milk must be done by constantly stirring so that there is no clumping of milk fat, it must be done carefully so as not to burn [12].

\subsection{Milk Packaging}

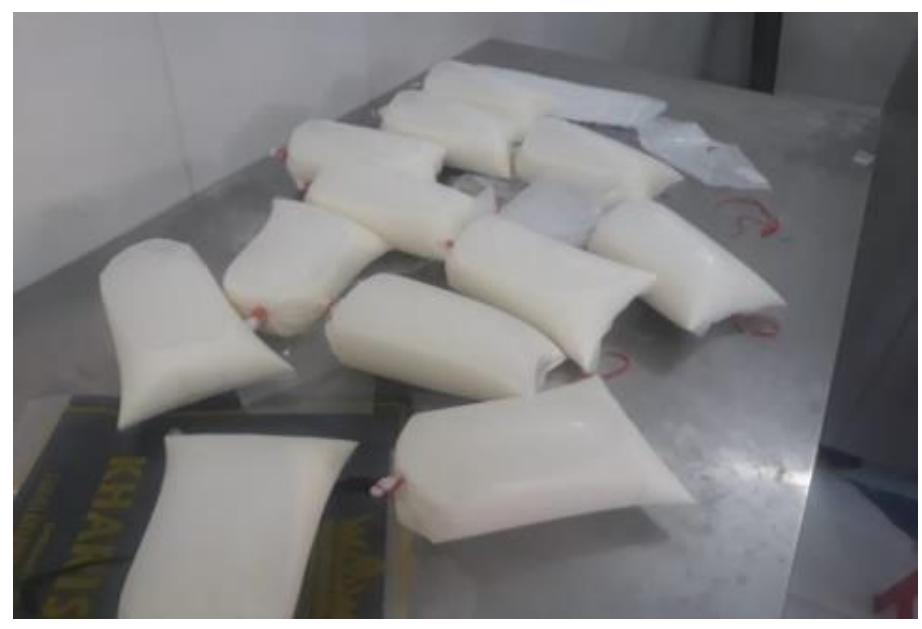

Post-Harvest Handling Holstein Friesian Milk at Susu Abadi Company in Tegal District (Krisjayanti Ataqwa and Melly Fera) 
Figure 7. Milk Packaging Process in Susu Abadi Companies

After the pasteurization process, the milk is put into a container and the milk is packed in a plastic bag with a volume of 1 liter. Packaged milk is cooled into the freezer. Besides being produced into various flavors of milk, the process of producing various flavors of milk is only adding sugar, powder, and flavor to taste, there is a time limit for the feasibility of consuming this milk which is only recommended for no more than 1 week [13].

\subsection{Milk Quality Check}

The composition of milk is an indicator to determine the quality of fresh milk quickly. Inspection of the quality of milk in susu abadi companies is carried out not only for the maintenance of milk for dairy cows but this company also conducts checks. Laboratory test to determine the quality of milk produced by taking milk samples to be checked for quality. Sampling is done by taking a sample of one bottle, each of which contains $(250-500 \mathrm{cc})$ milk. then given a mark on each bottle that contains; 1) Date, time and place for milk sampling, 2) Name of company owner and name of milk sample taker, and 3) Other information deemed important [14].

\subsection{The final product}

There are two products produced in susu abadi companies, namely fresh milk and pasteurized milk. Fresh milk is the main product at susu abadi companies. Fresh milk is milk that has been cooled down at a temperature of $0-4^{\circ} \mathrm{C}$ and has not been contaminated and has not been added with any substances resulting from milking that are not added with any ingredients obtained from healthy milking. Factors that must be considered are its hygiene by protecting milk from direct or indirect contact with sources that can contaminate milk during milking, collection and transportation. Dairy cow unit is the biggest potential in a susu abadi company with production reaching 200 liters per day. where $80 \%$ is distributed to cafes that have become customers of the susu abadi company. $15 \%$ are processed in pasteurized milk processing units and 5\% are traded directly to consumers [15].

Pasteurized milk is the second product at susu abadi company. Pasteurized milk is milk that is given heat treatment of $62-65^{\circ} \mathrm{C}$ for $30-60$ minutes which aims to kill pathogenic bacteria due to its relatively low heating process and relatively long time [16]. Pasteurized milk is another form of fresh milk and an attempt to extend its shelf life. Usually, this pasteurized milk will be sold directly to consumers at the cafe, namely the susu abadi cafe.

\section{Conclusion}

The amount of cow's milk production at the susu abadi company in one day is 125 liters on average and each cow produces 8 liters of milk in one day with the morning and evening milking time. The post-harvest processing of dairy cow's milk includes the process of milking, filtering milk, cooling the milk, heating the milk, packing milk, and checking the quality of the milk. The post-harvest handling method still uses semi-traditional methods. The final products are fresh milk and pasteurized milk.

\section{Acknowledgement}

Thank you to Mr. Muhamad Hasdar who has guided and helped finalize this article for publication and susu abadi company as a research site.

\section{Reference}


[1] A. Pasaribu, F. Firmansyah, dan N. Idris, "Analisis Faktor-Faktor Yang Mempengaruhi Produksi Susu Sapi Perah Di Kabupaten Karo Provinsi Sumatera Utara," J. Ilm. Ilmu-ilmu Peternak. Univ. Jambi, vol. XVIII, no. 1, pp. 28-35, 2015.

[2] Dzarnisa, P. Riski, B. P. Purwanto, dan A. Atabany, "Peningkatan Produksi dan Kualitas Susu Melalui Injeksi Bovine Somatotropin (bST) dan Suplementasi Seng Selama Masa Kering Pada Sapi Peranakan Fries Holland (PFH)," J. Pangan, vol. 20, no. 1, pp. 93-103, 2016.

[3] H. Ames, C. Glenton, dan S. Lewin, "Purposive sampling in a qualitative evidence synthesis: A worked example from a synthesis on parental perceptions of vaccination communication," BMC Med. Res. Methodol., vol. 19, no. 1, pp. 1-9, 2019.

[4] S. Jamshed, "Qualitative Research Method-Interviewing and Observation," J. Basic Clin. Pharm., vol. 5, no. 4, pp. 87, 2014.

[5] B. M. Miles, Huberman's A. Michael, dan S. Johnny, Qualitative Data Analysis: A Methods Sourcebook, Third edit. California: SAGE Publications, Inc., 1994.

[6] M. Hasdar, M. Fera, dan M. Syaifulloh, "Pemberdayaan Kelompok Bisnis Mahasiswa Berbasis IPTEK Melalui Program Agrofood Technopreneur," J. SOLMA, vol. 8, no. 1, pp. 73-79, 2019.

[7] N. S. Asminaya, B. P. Purwanto, N. Nahrowi, W. A. Ridwan, dan A. Atabany, "Efficiency of Milk Production and Feed Efficiency FH Cross Breed Fed Rice Straw during Dry Season," Int. J. Sci. Basic Appl. Res., vol. 34, no. 1, pp. 193-203, 2017.

[8] M. T. Luju, L. Hakim, dan S. Maylinda, "Estimation of Breeding Value of FH Dairy Cattle Milk Production in BBPTU-HPT Baturraden," Int. J. Sci. Res. Eng. Dev., vol. 2, no. 4, pp. 593-596, 2019.

[9] U. Wijayanti, Yuliati, dan T. Rahayu, "Higiene Dan Sanitasi Pada Susu Sapi Segar Di Desa Kayumas Kabupaten Klaten Ditinjau Dari Indikator Mikrobiologis,” J. Prodi Biol., vol. 6, no. 5, pp. 329-335, 2017.

[10] F. Navyanti dan R. Adriyani, "Higiene Sanitasi, Kualitas Fisik Dan Bakteriologi Susu Sapi Segar Perusahaan Susu X Di Surabaya," J. Kesehat. Lingkung., vol. 8, no. 1, pp. 36-47, 2015.

[11] N. S. Anindita dan D. . Soyi, "Studi kasus: Pengawasan Kualitas Pangan Hewani melalui Pengujian Kualitas Susu Sapi yang Beredar di Kota Yogyakarta," J. Peternak. Indones., vol. 19, no. 2, pp. 96-105, 2017.

[12] M. Rizal, E. Sumaryati, dan Suprihana, "Pengaruh Waktu dan Suhu Sterilisasi Terhadap Susu Sapi Rasa Coklat,” J. Ilmu-Ilmu Pertan. Agrika, vol. 10, no. 1, pp. 69-84, 2016.

[13] Miskiyah dan W. Broto, "Pengaruh Kemasan Terhadap Kualitas Dadih Susu Sapi," Bul. Peternak., vol. 35, no. 2, pp. 96, 2012.

[14] M. Arifin et al., "Kualitas Fisik , Kimia dan Mikrobiologi Susu Kambing pada Waktu Pemerahan yang Berbeda di Peternakan Cangkurawok, Balumbang Jaya, Bogor," J. Ilmu Produksi dan Teknol. Has. Peternak., vol. 04, no. 2, pp. 291-295, 2016.

[15] R. J. Yudonegoro, Nurwantoro, dan D. W. Harjanti, "Kajian Kualitas Susu Segar dari Tingkat Peternak Sapi Perah, Tempat Pengumpulan Susu dan Koperasi Unit Desa Jatinom di Kabupaten Klaten,” J. Peternak., vol. 3, no. 2, pp. 323-333, 2014.

[16] Z. Wulandari, E. Taufik, dan M. Syarif, "Kajian Kualitas Produk Susu Pasteurisasi Hasil Penerapan Rantai Pendingin,” J. Ilmu Produksi dan Teknol. Has. Peternak., vol. 5, no. 3, pp. 94-100, 2017. 